N. I. VYNNYK, A.V. LAVRENKO, I. P. KAIDASHEV, Z. O. SHAIENKO (Poltava, Ukraine)

\title{
OPTIMIZATION OF TREATMENT OF PATIENTS WITH INSULIN RESISTANCE TO REDUCE THE EXPRESSIVENESS OF CARDIOVASCULAR RISK FACTORS
}

\author{
HSEEU “Ukrainian Medical Stomatological Academy” <zlataligonenko@icloud.com>
}

\begin{abstract}
In patients with CHD and AH associated with MS the TG level is higher and HDL cholesterol is lower in the group with high insulin resistance (HOMA-index $7.52 \pm 0.74$ ), as compared to the group with low insulin resistance (HOMA-index 1,92 \pm 0.31$)$. More severe manifestations of CHD, namely, exertional angina pectoris and heart failure, have been found in individuals with high IR. Treatment with $30 \mathrm{mg}$ pioglitazone once daily during 3 months leads to reduction of IR level by 2 times, more significant lowering of TG level and increase of HDL cholesterol in patients with high IR. Thus, it has been confirmed that the leading factors of global cardiovascular risk is closely related to IR. It is proposed to consider the issue regarding the prophylactic use of $P G$ in individuals with high IR to reduce IR.
\end{abstract}

Key words: insulin resistance, pioglitazone, cardiovascular risk.

Insulin resistance (IR) is the underlying pathogenetic mechanism of both hidden and apparent type 2 diabetes mellitus (DM 2) and other components of the metabolic syndrome (MS), including the key factors for the development of global cardiovascular risk (GCR): dyslipidemia (DLP), arterial hypertension (AH), excessive weight, which make it reasonable to define the MS as an "insuline resistance syndrome" $[4,5$, 13]. Obesity, which is the major constitutional sign, currently used in the screening of the population to diagnose the MS, is only one of the multiple factors of the IR etiology [7, 16], and it is not always happened (it is worth remembering the so-called benign obesity without IR and MS [9, 10]).

There is a significant difference in the IR value for the DM 2 onset and other MS components, including DLP and AH. If DM 2 is the "natural endpoint" in the IR development, being at the stage of hyperinsulinemia and impaired tolerance to carbohydrates before manifestation [12], then DLP and AH occurs not in all individuals with IR and the mechanisms of correlation between the IR, AH and DLP are not so evident [15].

Pioglitazone (PG) is the agonist of the nuclear transcription factors (NTF), peroxisome proliferator-activated receptors gamma (PPAR $\gamma$ ) and is a drug, overcoming IR [3]. Study of the GCR indices in individuals with MS and various levels of IR before and after treatment with PG can provide the new data on the role of the IR in the formation of the factors, determining the prognosis, prophylaxis and treatment of the MS through the IR modulators.

Purpose. The paper is aimed at the study of the indices of blood pressure (BP), high density lipoprotein cholesterol (HDL cholesterol, $\alpha$-cholesterol), low density lipoprotein cholesterol (LDL cholesterol, $\beta$-cholesterol) and blood triglycerides (TG) as the leading factors for the GCR in the individuals with the MS, AH and coronary heart disease (CHD) in groups with various IR levels before and after taking PG along with combination treatment of $\mathrm{AH}$ and $\mathrm{CHD}$ during 3 months.

Methods and Materials. The study has been carried out at the Department of Internal Medicine III, Research Institute for Genetic and Immunological Grounds of Pathology and Pharmacogenetics of the Higher State Educational Establishment of Ukraine "Ukrainian Medical Stomatological Academy" and at the Therapeutic Unit of the Poltava First Municipal Clinical Hospital. 55 patients of both genders aged 45-75 years have been involved into clinical study. The mean age of the patients was (59 \pm 8 ) years. CHD and MS were diagnosed using the WHO criteria and modified criteria of the American Heart Association and International Diabetes Federation (IDF), respectively [11]. Before becoming involved into the clinical study all patients underwent screening to verify the diagnosis of CHD and MS. After screening, all 
patients were given recommendations on a dietary and lifestyle changes to achieve stabilization of the CHD indices, as well as received conventional medicamentous treatment during one month: $10 \mathrm{mg}$ atorvastatin once daily, $20 \mathrm{mg}$ isosorbide dinitrate twice a day, $10 \mathrm{mg}$ amlodipine once daily, $2.5-5 \mathrm{mg}$ bisoprolol once daily, $75 \mathrm{mg}$ acetylsalicylic acid once daily. Once the patients were included in to the study and underwent laboratory examination they were randomized into the study groups and control groups. $30 \mathrm{mg}$ pioglitazone (Pyoglar ${ }^{\circledR}$, Ranbaxy) once daily was included into the complex therapy of the study group, whereas patients from the control group received conventional medicamentous treatment only. The repeated examination was carried out following the 3 months.

Table 1. GCR factors in patients with various IR degrees (data on the groups with different HOMA indices before treatment in all patients, $n=55, M \pm m, 25 / 75$ percentiles)

\begin{tabular}{|c|c|c|c|c|}
\hline \multirow[b]{2}{*}{$\begin{array}{l}\text { Risk factors/HOMA, } \\
n\end{array}$} & \multicolumn{3}{|c|}{ Group } & \multirow[b]{2}{*}{$\begin{array}{c}\text { Reliability of } \\
\text { differences }\end{array}$} \\
\hline & $\begin{array}{c}\mathrm{I} \\
1.27 \pm 0.31 \\
(0.30-2.23) \\
n=15\end{array}$ & $\begin{array}{c}\text { II } \\
5.12 \pm 0.94 \\
(2.25-4.45) \\
n=24\end{array}$ & $\begin{array}{c}\text { III } \\
7.52 \pm 0.74 \\
(4.47-14.86) \\
n=16\end{array}$ & \\
\hline Triglycerides & $101,71 \pm 0.20$ & 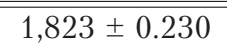 & $2.41 \pm 0.23$ & $P_{1}=0.74$ \\
\hline $0.45-1,86 \mathrm{mmol} / \mathrm{l}$ & $1,09 / 2.23$ & $1,26 / 2.22$ & $1,55 / 3.20$ & $\begin{array}{l}\mathrm{P}_{2}=0.15 \\
\mathbf{P}_{\mathbf{3}}=\mathbf{0 . 0 3}\end{array}$ \\
\hline$\alpha$-cholesterol & $1,710 \pm 0.095$ & $1,717 \pm 0.150$ & $1,50 \pm 0.07$ & $\mathrm{P}_{1}=0.96$ \\
\hline $0.9-1,9 \mathrm{mmol} / 1$ & $1,34 / 2$ & $1,4 / 2.14$ & $1,19 / 1,96$ & $\begin{array}{l}\mathrm{P}_{2}=0.18 \\
\mathrm{P}_{3}=0.09\end{array}$ \\
\hline Systolic BP & $176.050 \pm 1,301$ & $176.50 \pm 2.79$ & $177.88 \pm 1,64$ & $\mathrm{P}_{1}=0.86$ \\
\hline $\mathrm{mm} \mathrm{Hg}$ & $175 / 180$ & $170 / 185$ & $170 / 185$ & $\begin{array}{l}\mathrm{P}_{2}=0.66 \\
\mathrm{P}_{3}=0.41\end{array}$ \\
\hline Diastolic BP & $95.79 \pm 1,03$ & $96 \pm 1$ & $98.07 \pm 0.92$ & $\mathrm{P}_{1}^{3}=0.89$ \\
\hline $\mathrm{mm} \mathrm{Hg}$ & $90 / 100$ & $95 / 100$ & $95 / 100$ & $\begin{array}{l}\mathrm{P}_{2}=0.20 \\
\mathrm{P}_{3}=0.10\end{array}$ \\
\hline BMI & & $36.079 \pm 0.720$ & $37.42 \pm 0.97$ & $P_{1}=0.05$ \\
\hline $18.5-24.9 \mathrm{~kg} / \mathrm{m}$ & $\begin{array}{c}34.04 \pm 0.62 \\
32.26 / 35.1\end{array}$ & $34.105 / 37.25$ & $33.095 / 41,91$ & $\begin{array}{l}\mathrm{P}_{2}^{1}=0.42 \\
\mathbf{P}_{3}=\mathbf{0 . 0 1}\end{array}$ \\
\hline$\beta$ - lipoproteins & $2.110 \pm 0.136$ & $2.21 \pm 0.17$ & $2.615 \pm 0.160$ & $\mathrm{P}_{1}^{3}=0.68$ \\
\hline up to $3.4 \mathrm{~g} / \mathrm{L}$ & $1,69 / 2.45$ & $1,86 / 2.505$ & 1,98/3.307 & $\begin{array}{l}\mathrm{P}_{2}=0.16 \\
\mathbf{P}_{3}=\mathbf{0 . 0 3}\end{array}$ \\
\hline C-peptide & $6.15 \pm 0.94$ & $5.39 \pm 0.85$ & $8.12 \pm 0.93$ & $\mathrm{P}_{1}=0.59$ \\
\hline $0.5-3.2 \mathrm{ng} / \mathrm{mL}$ & $3.5 / 9.45$ & $3.425 / 7.975$ & $4.875 / 9.9$ & $\begin{array}{l}\mathrm{P}_{2}^{1}=0.09 \\
\mathrm{P}_{3}=0.15\end{array}$ \\
\hline IRI & $6.51 \pm 0.79$ & $13.51 \pm 0.55$ & $21,99 \pm 1,55$ & $P_{1}<0.001$ \\
\hline $2-25 \mu \mathrm{U} / \mathrm{mL}$ & $2.5 / 9.2$ & $13.085 / 14.87$ & $16.76 / 24.87$ & $\begin{array}{c}P_{2}^{1}=0.002 \\
P_{3}<0.001\end{array}$ \\
\hline Blood glucose & $5.33 \pm 0.18$ & $5.62 \pm 0.18$ & $7.09 \pm 0.41$ & $\mathrm{P}_{1}=0.31$ \\
\hline $4.2-6.1 \mathrm{mmol} / \mathrm{L}$ & $4.6 / 6$ & $5.225 / 5.90$ & $5.86 / 8.125$ & $\begin{array}{c}P_{2}=0.03 \\
P_{3}=0.001\end{array}$ \\
\hline Atherogenic ratio & $2.66 \pm 0.16$ & $2.89 \pm 0.308$ & $3.260 \pm 0.171$ & $\mathrm{P}_{1}=0.47$ \\
\hline $2-3$ & $2.19 / 3.24$ & $1,825 / 3.535$ & $2.68 / 3.79$ & $\begin{array}{c}P_{2}=0.28 \\
\mathbf{P}_{\mathbf{3}}=\mathbf{0 . 0 2 1}\end{array}$ \\
\hline
\end{tabular}

Note: $\mathrm{P}_{1}$ - between Group I and II; $\mathrm{P}_{2}$ - between Group II and III; $\mathrm{P}_{3}$ - between Group I and III.

TG and blood glucose was estimated by the conventional method using the testsystems (BIO-Lachema-Tect set, Czech Republic) and HDL cholesterol was determined by the standard technique [6]. The C-peptide concentration in the blood serum was determined by the immunoenzyme method using the test-systems. The level of the fasting serum immunoreactive insulin (IRI) was determined by the immunoenzyme method using the INSULIN ELISA (DRG, USA) test-system. The IR degree was assessed by the small model of homeostasis (Homeostasis Model Assessment - HOMA) 
with determination of the HOMA-IR index, which was developed by D. Matthews, et al. [18]: fasting insulin $(\mu \mathrm{U} / \mathrm{mL}) \mathrm{x}$ fasting glucose $(\mathrm{mmol} / \mathrm{l}) / 22.5$; the reference value is less than 2.77. The higher the HOMA index, the greater is the IR.

The statistical processing of the resulting data was carried out using the standard STATISTICA 6.0 software (StatSoft, USA) and "SPSS for Windows. Release 13.0" with calculation of the probability of the results obtained by the $T$-test for the pairwise and independent values $(t)$. The preliminary statistical analysis included the checking for normality using the Shapiro - Wilk test. The reliability of differences was determined by the Student's t-test. Methods of correlation analysis were also used. The difference between the values was considered to be statistically reliable when the error probability was $\mathrm{P}<0.05$. The data presented in the Tables and in the text are given as the mean values $(M \pm m)$ and interquartile range (the range between the $25^{\text {th }}$ and $75^{\text {th }}$ percentiles).

Results. Considering the fact, that patients' maximum and minimum level of IR, determined by the HOMA index was 15 times different (from 0.3 to 14.86), to study the correlation between the IR and GCR, before taking of PG, all 55 patients were assigned into tertiles: (1) with low IR: (HOMA $1.27 \pm 0.31),(0.30-2.23), n=15$; 2) with moderate IR: $5.12 \pm 0.94$ (2.25-4.45), $n=24$; 3) with high IR: (HOMA $7.52 \pm$ $0.74(4.47-14.86), n=16$. In the groups, where the difference in the mean HOMAindex was 4-6 times higher, the main factors for GCR have been calculated (Table 1). In the group with high IR, where the mean IR index was 6 time higher than in the group with low IR, the amount of TG and LDL cholesterol was $41 \%$ and $25 \%$, respectively, higher $(\mathrm{P}=0.03)$ with a tendency of HDL cholesterol lowering by $15 \%$ $(\mathrm{P}=0.09)$. Consequently, the atherogenic ratio was also higher (by $22 \%, \mathrm{P}=0.021)$. In both groups with elevated IR the Body Mass Index was increased, indicating about the relationship between the IR and obesity. The BP, both systolic (SBP) and diastolic (DBP), were equally elevated in all groups. Thus, the IR has a significant impact on such major factors for GCR as a high level of TG and LDL.

Table 2 presents data on PG effect on the IR indices.

Table 2. IR indices in the study groups of patients with CHD associated with MS before and after treatment with PG ( $M \pm m, 25 / 75$ percentiles)

\begin{tabular}{|c|c|c|c|c|c|}
\hline \multirow{3}{*}{$\begin{array}{c}\text { Group/ } \\
\text { Index, reference values }\end{array}$} & \multicolumn{4}{|c|}{ Clinical study groups } & \multirow{3}{*}{$\begin{array}{c}\text { Reliability of } \\
\text { differences }\end{array}$} \\
\hline & \multicolumn{2}{|c|}{ control group $(n=27)$} & \multicolumn{2}{|c|}{ study group $(n=28)$} & \\
\hline & $\begin{array}{l}\text { before treat- } \\
\text { ment }\end{array}$ & $\begin{array}{c}\text { following } 3 \\
\text { months after } \\
\text { treatment }\end{array}$ & $\begin{array}{l}\text { before treat- } \\
\text { ment }\end{array}$ & $\begin{array}{c}\text { following } 3 \\
\text { months after } \\
\text { treatment }\end{array}$ & \\
\hline Body Mass Index & $\begin{array}{l}35.34 \pm 3.62 \\
33.2 / 36.75\end{array}$ & $\begin{array}{l}35.35 \pm 3.67 \\
32.97 / 36.75\end{array}$ & $\begin{array}{l}36.65 \pm 4.57 \\
32.77 / 40.96\end{array}$ & $\begin{array}{l}36.10 \pm 4.37 \\
32.77 / 39.77\end{array}$ & $\begin{array}{l}\mathrm{P}_{1}=0.24260 \\
\mathrm{P}_{2}=0.77246 \\
\mathbf{P}_{3}=\mathbf{0 . 0 0 0 0 1} \\
\mathrm{P}_{4}=0.49147\end{array}$ \\
\hline IRI, $2-25 \mu \mathrm{lU} / \mathrm{ml}$ & $\begin{array}{l}11.39 \pm 5.82 \\
7.31 / 15.6\end{array}$ & $\begin{array}{l}16.16 \pm 9.98 \\
10.9 / 17.9\end{array}$ & $\begin{array}{l}18.68 \pm 10.29 \\
11.90 / 24.17\end{array}$ & $\begin{array}{l}10.86 \pm 4.19 \\
7.475 / 13.35\end{array}$ & $\begin{array}{l}\mathrm{P}_{1}=\mathbf{0 . 0 0 2 1 9} \\
\mathrm{P}_{2}=0.05697 \\
\mathbf{P}_{3}=\mathbf{0 . 0 0 0 3 4} \\
\mathbf{P}_{4}=\mathbf{0 . 0 1 2 4 7}\end{array}$ \\
\hline $\begin{array}{l}\text { C-peptide, } \\
0.5-3.2 \mathrm{ng} / \mathrm{ml}\end{array}$ & $\begin{array}{l}6.10 \pm 3.55 \\
3.98 / 8.13\end{array}$ & $\begin{array}{l}7.54 \pm 3.50 \\
5.0 / 8.40\end{array}$ & $\begin{array}{l}7.77 \pm 4.83 \\
4.6 / 10.7\end{array}$ & $\begin{array}{l}6.39 \pm 3.36 \\
4.05 / 9.075\end{array}$ & $\mathrm{P}_{1}-\mathrm{P}_{4}>0.1$ \\
\hline $\begin{array}{l}\text { Blood glucose, } \\
4.2-6.1 \mathrm{mmol} / 1\end{array}$ & $\begin{array}{l}5.95 \pm 1.30 \\
5.2 / 6.3\end{array}$ & $\begin{array}{l}6.53 \pm 1.25 \\
5.8 / 7.1\end{array}$ & $\begin{array}{l}6.47 \pm 2.10 \\
5.125 / 7.15\end{array}$ & $\begin{array}{l}5.76 \pm 1.56 \\
5.03 / 6.08\end{array}$ & $\begin{array}{l}\mathrm{P}_{1}=0.27528 \\
\mathrm{P}_{2}=0.05816 \\
\mathrm{P}_{3}=0.05553 \\
\mathbf{P}_{4}=\mathbf{0 . 0 4 8 0 3}\end{array}$ \\
\hline HOMA index & $\begin{array}{l}3.07 \pm 1.84 \\
1.7 / 4.57\end{array}$ & $\begin{array}{l}4.76 \pm 3.11 \\
2.51 / 5.96\end{array}$ & $\begin{array}{l}5.67 \pm 3.93 \\
2.81 / 7.92\end{array}$ & $\begin{array}{l}2.98 \pm 1.91 \\
1.77 / 3.56\end{array}$ & $\begin{array}{l}P_{1}=0.00286 \\
P_{2}=0.02659 \\
P_{3}=0.00045 \\
P_{4}=0.00992\end{array}$ \\
\hline
\end{tabular}

Note: the comparison of indices between the groups before $\left(\mathrm{P}_{1}\right)$ and after $\left(\mathrm{P}_{4}\right)$ treatment has been carried out using the Student's t-test, inside the groups $\left(\mathrm{P}_{2} \mathrm{P}_{3}\right)$ for the pairwise variables 
Indices, presented in Table 2. show a significant (by 2 times) PG-related lowering of IR, judging by the HOMA-index. However, this index was 1,7. times higher $(\mathrm{P}<$ $0.001)$ in the controls during the similar period, confirming the fact that it was the $\mathrm{PG}$, and not a diet, lifestyle changes and comprehensive treatment of CHD and AH that has an effect on IR lowering. Noteworthy, the intake of $30 \mathrm{mg} /$ day PG during 3 months did not lead to weight gain, and, on the contrary, the BMI was tending to decrease by $1.5 \%(\mathrm{P}=0.00034)$, that is not consistent with a number of studies reporting about the increase of BMI, which, in the opinion of the researchers, is associated with fluid retention and heart failure progression, considered to be one of the negative side effects of glitazones [2, 3].

Table 3 shows data on the PG effect on the indices of the lipid metabolism.

Table 3. Indices of lipid metabolism in patients with CHD associated with MS before and after treatment with PG ( $M \pm m, 25 / 75$ percentiles)

\begin{tabular}{|c|c|c|c|c|c|}
\hline \multirow{3}{*}{ Index } & \multicolumn{4}{|c|}{ Clinical study groups } & \multirow{3}{*}{$\begin{array}{l}\text { Reliability of } \\
\text { differences }\end{array}$} \\
\hline & \multicolumn{2}{|c|}{ control group $(n=27)$} & \multicolumn{2}{|c|}{ study group $(n=28)$} & \\
\hline & $\begin{array}{l}\text { before treat- } \\
\text { ment }\end{array}$ & $\begin{array}{c}\text { following } 3 \\
\text { months after } \\
\text { treatment }\end{array}$ & $\begin{array}{l}\text { before treat- } \\
\text { ment }\end{array}$ & $\begin{array}{l}\text { following } 3 \text { months } \\
\text { after treatment }\end{array}$ & \\
\hline $\begin{array}{l}\text { Triglycerides, } \\
\text { mmol/1 }\end{array}$ & $\begin{array}{c}1.77 \pm 0.90 \\
0.96 / 2.36\end{array}$ & $\begin{array}{c}1.98 \pm 0.79 \\
1.41 / 2.7\end{array}$ & $\begin{array}{c}2.34 \pm 1.10 \\
1.43 / 3.08\end{array}$ & $\begin{array}{c}1.38 \pm 0.80 \\
0.82 / 1.62\end{array}$ & $\begin{array}{l}\mathbf{P}_{1}=\mathbf{0 . 0 4 2 9 3} \\
\mathrm{P}_{2}=0.35650 \\
\mathbf{P}_{3}=\mathbf{0 . 0 0 0 0 2} \\
\mathrm{P}_{4}=0.00689\end{array}$ \\
\hline$\alpha$-Cholesterol, & $1.68 \pm 0.45$ & $1.50 \pm 0.36$ & $1.55 \pm 0.40$ & $1.57 \pm 0.37$ & $\mathrm{P}_{1}=0.25228$ \\
\hline $0.9-1,9 \mathrm{mmol} / \mathrm{l}$ & $1.34 / 2.08$ & $1.33 / 1.73$ & $1.25 / 1.88$ & 1.3/1.93 & $\begin{array}{l}\mathrm{P}_{2}=0.19251 \\
\mathrm{P}_{3}=0.85541 \\
\mathrm{P}_{4}=0.99571\end{array}$ \\
\hline$\beta$ - Lipoproteins, & $2.19 \pm 0.58$ & $2.21 \pm 0.97$ & $2.54 \pm 0.85$ & $1.78 \pm 0.69$ & $\mathrm{P}_{1}=0.08467$ \\
\hline $\mathrm{g} / \mathrm{l}$ & $1.78 / 2.5$ & $1.55 / 2.79$ & $1.74 / 3.32$ & $1.47 / 1.87$ & $\begin{array}{l}\mathrm{P}_{2}=0.94190 \\
\mathbf{P}_{3}=\mathbf{0 . 0 0 0 0 4} \\
\mathrm{P}_{4} *=0.06445\end{array}$ \\
\hline $\begin{array}{l}\text { Cholesterol, } \\
\mathrm{mmol} / \mathrm{l}\end{array}$ & $\begin{array}{c}6.01 \pm 1.49 \\
4.48 / 7.24\end{array}$ & $\begin{array}{c}6.35 \pm 2.11 \\
5.15 / 7.14\end{array}$ & $\begin{array}{c}6.50 \pm 1.56 \\
5.48 / 7.18\end{array}$ & $\begin{array}{c}5.14 \pm 1.14 \\
4.2 / 5.84\end{array}$ & $\begin{array}{l}\mathrm{P}_{1}=0.24708 \\
\mathrm{P}_{2}=0.42371 \\
\mathbf{P}_{3}=\mathbf{0 . 0 0 0 2 1} \\
\mathbf{P}_{4}=\mathbf{0 . 0 1 0 4 0}\end{array}$ \\
\hline $\begin{array}{l}\text { Total lipids, } \\
4-8 \mathrm{~g} / 1\end{array}$ & $\begin{array}{c}5.65 \pm 1.70 \\
4.4 / 6.9\end{array}$ & $\begin{array}{c}6.94 \pm 2.58 \\
5.2 / 8.6\end{array}$ & $\begin{array}{c}6.63 \pm 1.77 \\
5.2 / 8.0\end{array}$ & $\begin{array}{c}4.83 \pm 1.43 \\
3.8 / 5.4\end{array}$ & $\begin{array}{l}P_{1}=0.04213 \\
P_{2}=0.00511 \\
P_{3}=0.00003 \\
P_{4}=0.00042\end{array}$ \\
\hline $\begin{array}{l}\text { Atherogenic } \\
\text { ratio, } \\
2-3\end{array}$ & $\begin{array}{c}2.66 \pm 0.72 \\
2.18 / 3.04\end{array}$ & $\begin{array}{c}3.20 \pm 1.57 \\
1.78 / 3.9\end{array}$ & $\begin{array}{c}3.30 \pm \\
0.908 \\
2.76 / 3.85\end{array}$ & $\begin{array}{c}2.41 \pm 1.01 \\
1.63 / 2.98\end{array}$ & $\begin{array}{l}\mathbf{P}_{1}=\mathbf{0 . 0 0 5 5 1} \\
\mathrm{P}_{2}=0.12370 \\
\mathbf{P}_{3}=\mathbf{0 . 0 0 0 2 1} \\
\mathbf{P}_{4}=\mathbf{0 . 0 3 0 6 5}\end{array}$ \\
\hline
\end{tabular}

Note: notations are similar to the ones in Table 2

No significant enhancement of the indices of lipid metabolism has been noted in patients, who received conventional treatment; moreover, the increase in the level of the total cholesterol (from $6.01 \mathrm{mmol} / \mathrm{l} \pm 1.49 \mathrm{mmol} / \mathrm{l}$ to $6.35 \mathrm{mmol} / \mathrm{l} \pm 2.11 \mathrm{mmol} / \mathrm{l}$ ), total lipids (by $23 \% ; \mathrm{P}_{2}<0.01$ ), TG (from $1.77 \mathrm{mmol} / 1 \pm 0.90 \mathrm{mmol} / 1$ to $1.98 \mathrm{mmol} / \mathrm{l}$ $\pm 0.79 \mathrm{mmol} / \mathrm{l}$ ), $\beta$-lipoproteins (from $2.19 \mathrm{~g} / 1 \pm 0.58 \mathrm{~g} / 1$ to $2.21 \mathrm{~g} / \mathrm{l} \pm 0.97 \mathrm{~g} / \mathrm{l}$ ), atherogenic ratio (from $2.66 \pm 0.72$ to $3.20 \pm 1.57$ ) was observed during the treatment period. On the contrary, the study group showed, despite the higher rates of lipid metabolism before the therapy, PG-related significant reduction of all lipid metabolism indices, except for the $\alpha$-cholesterol level, namely, TG (by 1.7 times; $\mathrm{P}<0.01$ ), $\beta$-lipoproteins (by 1.43 times; $\mathrm{P}_{3}<0.001$ ), cholesterol (by 1.26 times; $\mathrm{P}<0.001$ ), total lipids (1.37 times; $\mathrm{P}<0.001$ ) and atherogenic ratio (by 1.37 times; $\mathrm{P}<0.001$ ). 
The comparison of the lipid metabolism indices after therapy showed that the reliable difference between the study groups was found in the amount of TG $(\mathrm{P}<0.001)$, cholesterol $(\mathrm{P}<0.02)$, total lipids $(\mathrm{P}<0.001)$ and in atherogenic ratio $(\mathrm{P}<0.05)$.

The additional information regarding the correlation between the IR and GCR has been obtained by the correlation analysis. However, no correlation between the BMI and these indices has been found $(r=0.02-0.1 ; \mathrm{P}>0.2)$.

Table 4 shows the data on the effect of IR and PG-therapy on the incidence of various clinical forms of CHD in the study group.

Table 4. Incidence of the specific clinical forms of CHD in patients with different levels of IR, as well as before and after treatment with PG during 3 months

\begin{tabular}{|c|c|c|c|c|c|}
\hline \multirow{3}{*}{ CHD forms } & \multicolumn{4}{|c|}{ Clinical study groups } & \multirow{3}{*}{$\begin{array}{l}\text { Reliability of } \\
\text { differences }\end{array}$} \\
\hline & \multicolumn{2}{|c|}{$\begin{array}{c}\text { all patients } \\
(n=55)\end{array}$} & \multicolumn{2}{|c|}{$\begin{array}{c}\text { control group } \\
(n=28)\end{array}$} & \\
\hline & $\begin{array}{c}\text { high IR, } \\
n=40\end{array}$ & $\begin{array}{c}\text { low IR, } \\
n=15\end{array}$ & $\begin{array}{l}\text { before } \\
\text { treatment }\end{array}$ & $\begin{array}{c}\text { following the } 3 \text { months } \\
\text { after treatment }\end{array}$ & \\
\hline $\begin{array}{l}\text { Class I angina } \\
\text { pectoris }\end{array}$ & 0 & 0 & 0 & 4 & $\begin{array}{l}\chi^{2}=6.4 \\
\mathrm{P}<0.01\end{array}$ \\
\hline $\begin{array}{l}\text { Class II angina } \\
\text { pectoris }\end{array}$ & 27 & 10 & 20 & 18 & $\mathrm{P}=0.014$ \\
\hline $\begin{array}{l}\text { Class III angina } \\
\text { pectoris }\end{array}$ & 13 & 5 & 8 & 6 & \\
\hline Class I heart failure & 0 & 3 & 0 & 5 & $\chi^{2}=8.2$ \\
\hline $\begin{array}{l}\text { Class II } \\
\text { Heart failure }\end{array}$ & 19 & 11 & 14 & 10 & $\mathrm{P}<0.01$ \\
\hline $\begin{array}{l}\text { Class III } \\
\text { Heart failure }\end{array}$ & 24 & 1 & 14 & 13 & $\mathrm{P}=0.014$ \\
\hline
\end{tabular}

Notes: the comparison of indices in the groups with high and low IR has been carried out using the $\chi^{2}$ test; Wilcoxon test was used in the group before and after treatment for pairwise variables; the Groups II and III, where the mean values of the IR were 4 and 6 times, respectively, higher than in Group I, were joined

The present data show that higher IR level (in the joined group) is clinically expressed in more severe forms of angina pectoris and heart failure. 3-month treatment with PG, as was mentioned above (Table 2), which lowers the IR level by 2 times, results in significant reduce of the severity of angina pectoris and heart failure.

Discussion. The most significant finding of our study is the establishment of the correlation between the IR and dyslipidemia. This correlation is manifested by the elevated TG and $\beta$-LP and the tendency of $\alpha$-cholesterol to decrease in the group, where the HOMA index was 6 times higher than in the group with a low IR and was confirmed by the results of patients' treatment with PG, leading to the IR reduction by 2 times and significant enhancement of the lipid metabolism indices (see Tables 1-3).

Correlation analysis indicates that it is the IL, and not the obesity, that is a factor for the development of dyslipidemia. The moderate correlation $(r=0.34 ; \mathrm{P}<0.01)$ between the IR and the TG and $\beta$-LP level has been established, whereas no correlation between the BMI and the hyperlipidemia indices $(r=0.06 ; \mathrm{P}>0.3)$ has been found.

Our study shows that about $1 / 3$ of patients who, according to the IDF criteria, experience MS, have a low IR. In this group the TG and $\beta$-LP level is lower and, most importantly, milder forms of $\mathrm{CHD}$, namely, exertional angina pectoris and heart failure, are found.

Therefore, it is the IR level, but not the BMI values, that is relevant to determining the GCR degree.

IR occurs long before the DM 2 manifestation, possibly already in the child age [1] and is the leading factor of GCR. Numerous prospective studies show that cardiovascular diseases start developing well before the manifestations of DM 2 [8]. Conse- 
quently, the prevention of cardiovascular diseases should be based on the determination of the IR degree.

Numerous multicenter studies aimed at determining the impact of the various modes of hyperglycemia treatment and their meta-analyses [17] have shown that "hard" control of the glycated hemoglobin level has only a moderate effect on the risk of the development of cardiovascular complications (CVC), indicating about the importance of other factors, not only hyperglycemia, in their development. At the same time, studies aimed at the correction of dyslipidemia and $\mathrm{AH}$ have been more productive in term of the overall and cardiovascular mortality [14]. We hypothesize that determination and correction of the IR can contribute to decrease the GCR. In this respect, the findings of our research on the effect of PG are very significant.

Although our study has found no correlation between the IR degree and AH both before and after treatment with PG, which may be related to the prolonged course and severity of $\mathrm{AH}$ in patients from the study group, the very fact of the occurrence of $\mathrm{AH}$ in $100 \%$ of the examined individuals indicates about the existence of such correlation.

G. M. Reaven et al. [14] has studied the lipid metabolism indices in 126 adult patients of both genders with mild AH and the similar level of BP, but with different sensitivity to insulin. It has been established that in the group with expressed IR and similar level of cholesterol and LDL, the higher TG and lower HDL amount was noted. The high IR has been found in the untreated individuals with $\mathrm{AH}$ with no clinical manifestations, but with the signs of CHD, based on the criteria of the "Minnesota Code" for ECG classification [14].

The studies of I. P. Kaidashev [4] have shown that IR is a consequence of the activation of nuclear factor-kappa $\mathrm{B}(\mathrm{NF}-\mathrm{kB})$. In this respect, our study shows that PPAR- $\gamma$, judging by the effect of PG, is the antagonist of $\mathrm{NFkB}$, which coincides with the experimental data we have previously received [6].

Conclusions. In the group of patients with CHD and AH, meeting the MS (IDF) criteria, the maximum and minimum IR levels, determined by the HOMA index, are 15 times different (from 0.3 to 14.86). The IR is associated with dyslipidemia and AH that are the global factors for cardiovascular risk. The IR correction is one of the important strategic lines for the prevention of cardiovascular diseases, which should be applied long before the onset of diabetes mellitus 2. being the end point of the IR development. Consideration should be given to the possibility of preventive prescription of medications that reduce the IR to individuals who, for various reasons, cannot adjust the IR through a diet and physical exercise.

\section{References}

1. Васюкова О. В. Проект международного консенсуса по ожирению у детей // Эндокринол. вестн. - 2006. - Т. 11, № 1. C. 8-9.

2. Винник Н. И., Кайдашев И. П. Клиническая характеристика эффективности пиоглитазона в комплексной терапии больных с ишемической болезнью сердца на фоне метаболического синдрома // Лік. справа=Врачеб. дело. - 2011. - № 1-2. C. 82-89.

3. Винник Н. И., Куценко Л. А., Куценко Н. Л. и др. Эффективность применения пиоглитазона в комплексной терапии больных ишемической болезнью сердца на фоне метаболического синдрома // Лік. справа=Врачеб. дело. - 2011. - № 3-4. - С. 67-73.

4. Кайдашев И. П. NF-kB-сигнализация как основа развития системного воспаления, инсулинорезистентности, липотоксично-
1. Vasyukova O. V. Proekt mezhdunarodnogo konsensusa po ozhireniyu u detey // Endokrinol. vestn. - 2006. - T. 11, № 1. S. 8-9.

2. Vinnik N. I., Kaidashev I. P. Klinicheskaya harakteristika effektivnosti pioglitazona $\mathrm{v}$ kompleksnoy terapii bolnyih s ishemicheskoy boleznyu serdtsa na fone metabolicheskogo sindroma // Lik. sprava=Vracheb. delo. - 2011. - № 1-2. - S. 82-89.

3. Vinnik N. I., Kutsenko L. A., Kutsenko N. L. [ta in.] Effektivnost primeneniya pioglitazona $\mathrm{V}$ kompleksnoy terapii bolnyih ishemicheskoy boleznyu serdtsa na fone metabolicheskogo sindroma // Lik. sprava=Vracheb. delo. 2011. - №. 3-4. - S. 67-73.

4. Kaidashev I. P. NF-kB-signalizatsiya kak osnova razvitiya sistemnogo vospaleniya, insulinorezistentnosti, lipotoksichnosti, sahar- 
сти, сахарного диабета 2-го типа и атеросклероза // Междунар. эндокринол. журн. - 2011. - № 3. - С. 56-65.

5. Расін М. С., Шаєнко 3. О. Сучасні методи корекції системного запалення та інсулінорезистентності у хворих ішемічною хворобою серця і цукровим діабетом 2 типу // Лік. справа=Врачеб. дело. 2014. - № 3-4. - C. 60-65.

6. Расін О. М., Кайдашев І. П., Расін М. С. Молекулярні механізми протизапальної дії глітазонів та статинів: роль PPAR- $\gamma / /$ Міжнар. ендокринол. журн. - 2007. Вип. 12, № 6. - С. 71-76. nogo diabeta 2-go tipa i ateroskleroza // Mezhdunar. endokrinol. zhurn. - 2011. №.3. - S. 56-65.

5. Rasin M. S., Shaienko Z. O. Suchasni metody korektsii systemnoho zapalennia ta insulinorezystentnosti u khvorykh ishemichnoiu khvoroboiu sertsia i tsukrovym diabetom 2 typu // Lik. sprava=Vracheb. delo. 2014. - №. 3-4 (1127). - S. 60-65.

6. Rasin O. M., Kaidashev I. P., Rasin M.S. Molekuliarni mekhanizmy protyzapalnoi dii hlitazoniv ta statyniv: rol PPAR- $\gamma$ // Mizhnarod. endokrynol. zhurn. - 2007. - №. 6 (12). - S. 71-76.

7. De Fronzo R. A. Insulin resistance, lipotoxicity, type 2 diabetes and atherosclerosis: the missing links. The Claude Bernard Lecture 2009 // Diabetologia. - 2010. - Vol. 53. - P. 1270-1287.

8. Egger G. Obesity, Chronic Disease, and Economic Growth: A Case for "Big Picture” // Advances in Preventive Med. - 2011. - Vol. 2011. - Article ID 149158. - 6 pages.

9. Esler M. D., Krum H., Sobotka P. A. et al. Renal sympathetic denervation in patients with treatment-resistant hypertension (The Symplicity HTN-2 Trial): a randomized controlled trial // Lancet. - 2010. - Vol. 376. - P. 1903-1909.

10. Facchini F. S., Nascimento C. D., Reaven G. M. et al. Blood pressure, insulin resistance, and urinary nitrate excretion // Hypertension. - 1999. - Vol. 33. - P. 1008-1012.

11. Grundy S. M., Brewer H. B.Jr., Cleeman J. Definition of metabolic syndrome: Report of the National Heart, Lung, and Blood Institute // Am. Heart Association conference on scientific issues related to definition Circulation. - 2004. - Vol. 109. - P. 433-438.

12. Himsworth H. P. The mechanism of diabetes mellitus // Human diabetes mellitus. Lancet. 1939. - Vol. 2. - P. 171-175.

13. Hoehn K. L., Salmon A. B., Hohnen-Behrens C. et al. Insulin resistance is a cellular antioxidant defense mechanism // Proceedings of the National Acad. of Sciences of the United States of Am. - 2009. - Vol. 106, N 42. - P. 17787-17792.

14. Reaven G. M. Relationships Among Insulin Resistance, Type 2 Diabetes, Essential Hypertension, and Cardiovascular Disease: Similarities and Differences / The J. of Clin. Hypertension. 2011. - Vol. 13. - P. 238-243.

15. Reaven G. M., Chen Y-D. I., Hollenbeck C. B. et al. Plasma insulin, C-peptide, and proinsulin concentrations in obese and nonobese individuals with varying degrees of glucose tolerance $/ / \mathrm{J}$. Clin. Endocrinol. Metab. - 1993. - Vol. 76. - P. 44-48.

16. Tamura Y., Tanaka Y., Sato F. et al. "Effects of diet and exercise on muscle and liver intracellular lipid contents and insulin sensitivity in type 2 diabetic patients" // The J. of Clin. Endocrinol. and Metabolism. - 1959. - Vol. 90, N 6. - P. 3191-3196.

17. Turnbull F. M., Abraira C., Anderson R.J. et al. Intensive glucose control and macrovascular outcomes in type 2 diabetes // Diabetologia. - 2009. - Vol. 52. - P. 2288-2298.

18. Wallace T. M., Mattheres D. R. The assessment of insulin resistance in man // Diabetic Med. 2002. - Vol. 19. - P. 527-534.

\section{ОПТИМІЗАЦІЯ ЛІКУВАННЯ ХВОРИХ $З$ ІНСУЛІНОРЕЗИСТЕНТНІСТЮ $З$ МЕТОЮ ЗНИЖЕННЯ ВИРАЖЕНОСТІ ФАКТОРІВ КАРДІОВАСКУЛЯРНОГО РИЗИКУ}

\section{Н. І. Винник, А. В. Лавренко, І. П. Кайдашев, З. О. Шаєнко (Полтава)}

У хворих на ішемічну хворобу серця (IXC) і артеріальну гіпертензію (АГ) на фоні метаболічного синдрому (MC) рівень тригліцеридів (ТГ) вищий, а холестерину ліпопротеїдів високої щільності (ХЛПВЩ) нижчий в групі з високою інсулінорезистентністю - IP (індекс HOMA 7,52 \pm 0,74) порівняно $з$ аналогічною групою хворих з низькою IP (НОМА 1,92 $\pm 0,31$ ). В осіб з високою IP відмічено більш виражені прояви IXC: стенокардію напруги і серцеву недостатность. Лікування піоглітазоном по 30 мг/доба протягом 3 міс приводить до зниження рівня IP в 2 рази, значнішого зменшення рівня ТГ та підвищення рівня ХЛПВЩ в осіб з високою IP. Таким чином, підтверджено, що головні чинники глобального кардіоваскулярного ризику тісно пов'язані з IP. Пропонується розглянути питання про можливість профілактичного застосування піоглітазоном в осіб з високою IP як засобу, що знижує IP.

Ключові слова: інсулінорезистентність, піоглітазон, кардіоваскулярний ризик. 
ОПТИМИЗАЦИЯ ЛЕЧЕНИЯ БОЛЬНЫХ С ИНСУЛИНОРЕЗИСТЕНТНОСТЬЮ

С ЦЕЛЬЮ СНИЖЕНИЯ ВЫРАЖЕННОСТИ ФАКТОРОВ КАРДИОВАСКУЛЯРНОГО РИСКА

\section{Н. И. Винник, А. В. Лавренко, И. П. Кайдашев, З. А. Шаенко (Полтава)}

У больных ишемической болезнью сердца (ИБС) и артериальной гипертензией (АГ) на фоне метаболического синдрома (МС) уровень триглицеридов (ТГ) выше, а холестерина липопротеидов высокой плотности (ХЛПВП) ниже в группе с высокой инсулинорезистентностью - ИР (индекс НОМА 7,52 $\pm 0,74$ ) по сравнению с аналогичной группой больных с низкой ИР (НОМА 1,92 \pm 0,31). У лиц с высокой ИР отмечены более выраженные проявления ИБС: стенокардия напряжения и сердечная недостаточность. Лечение пиоглитазоном по 30 мг/сут в течение з мес приводит к снижению уровня ИР в 2 раза, значительному уменьшению уровня ТГ и повышению уровня ХЛПВП у лиц с высокой ИР. Таким образом, подтверждено, что основные факторы глобального кардиоваскулярного риска тесно связаны с ИР. Предлагается рассмотреть вопрос о возможности профилактического применения пиоглитазоном у лиц с высокой ИР как средства, снижающего ИР.

Ключевые слова: инсулинорезистентность, пиоглитазон, кардиоваскулярный риск. 